\title{
Penentuan Variabel Berpengaruh dalam Pengembangan Kawasan Strategis Ekonomi Pesisir Utara pada Bidang Perikanan di Kota Pasuruan
}

\author{
Dwi Putri Heritasari dan Rulli Pratiwi Setiawan \\ Perencanaan Wilayah dan Kota, Fakultas Teknik Sipil dan Perencanaan, \\ Institut Teknologi Sepuluh Nopember (ITS) \\ Jl. Arief Rahman Hakim, Surabaya 60111 Indonesia \\ e-mail: rulli.setiawan@urplan.its.ac.id
}

\begin{abstract}
Abstrak-Penetapan kawasan strategis ekonomi di wilayah pesisir utara Kota Pasuruan, sesuai dengan tujuannya yakni harus mampu meningkatkan kesejahteraan masyarakat pesisir melalui pengembangan ekonomi lokal pada bidang perikanan. Pengembangan kawasan dilakukan dengan berlandaskan pada konsep pembangunan berkelanjutan yakni pembangunan yang menitikberatkan pada empat pilar pembangunan yaitu lingkungan, sosial budaya, ekonomi, dan politik kelembagaan yang harus saling terkait dan seimbang. Akan tetapi, pada kawasan strategis ekonomi pesisir utara Kota Pasuruan ini kegiatan perikanannya belum menampakkan keseimbangan dari segi pengelolaan lingkungan, kondisi sosial masyarakat, pertumbuhan ekonomi, serta politik kelembagaannya. Artikel ini adalah bagian dari penelitian terkait pengembangan kawasan strategis ekonomi wilayah pesisir utara pada bidang perikanan di Kota Pasuruan, dimana artikel ini memuat proses awal dalam penelitian tersebut. Pada artikel ini akan dibahas dan didapatkan variabel yang berpengaruh dalam pengembangan kawasan strategis ekonomi pesisir utara Kota Pasuruan yang selanjutnya akan menjadi input dalam penilaian tingkat keberlajutan sampai pada perumusan strategi pengembangan kawasan strategis ekonomi pesisir utara Kota Pasuruan.
\end{abstract}

Kata Kunci-Kawasan Strategis Ekonomi, Pembangunan Berkelanjutan, Strategi, Wilayah Pesisir

\section{PENDAHULUAN}

$\mathrm{K}$ AWASAN pesisir Kota Pasuruan berada pada koridor pantai utara (Pantura) Jawa. Kota Pasuruan merupakan kawasan strategis yang memberikan kontribusi besar pada kegiatan ekonomi khususnya pada pergerakan perindustrian dan perdagangan, hal ini dikarenakan lokasi Kota Pasuruan berada di persimpangan segitiga emas jalur regional SurabayaProbolinggo-Malang dengan jarak $60 \mathrm{~km}$ ke Surabaya, $38 \mathrm{~km}$ ke Probolinggo dan $54 \mathrm{~km}$ ke Malang. Perkembangan PDRB Kota Pasuruan Atas Dasar Harga Konstan 2000 mengalami peningkatan, yakni dari sebesar 1.117.314.476 (ribu rupiah) pada tahun 2010 menjadi sebesar 1.187.593.197 (ribu rupiah) pada tahun 2011, sampai pada tahun 2012 sebesar 1.264.357.628 (ribu rupiah) [1]. Peningkatan jumlah PDRB Kota Pasuruan ini menyebabkan kegiatan perekonomian Kota Pasuruan semakin banyak, sehingga pemanfaatan lahan budidaya semakin besar pula. Dari total luas wilayah Kota Pasuruan, sekitar $65.85 \%$-nya berupa wilayah terbangun. Kecamatan Panggungrejo yang merupakan salah satu kecamatan pesisir di Kota Pasuruan memiliki luas terbangun mencapai $70 \%$ dari total luasnya [2].

Kota Pasuruan mengalami kemajuan yang sangat pesat. Kegiatan ekonomi kota yang dulunya mendapat dukungan utama dari sektor pertanian dan perikanan, saat ini telah berkembang sektor ekonomi yang lain, yaitu perdagangan dan jasa serta industri, dimana industri yang dominan yaitu mebel dan kerajinan logam. Dengan dukungan ekonomi kota tersebut infrastruktur pelayanan kota turut berkembang yang membuat Kota Pasuruan semakin dinamis. Sebaliknya, kekuatan dinamis kota masih kurang mampu memberi pengaruh positif secara maksimal terhadap wilayah Pesisir Utara Kota Pasuruan.

Pada tahun 2012, tiga kelurahan yang berada di kawasan utara Kota Pasuruan yakni Kelurahan Tambaan, Ngemplakrejo, Panggungrejo, telah ditetapkan sebagai kawasan strategis dari sudut kepentingan aspek ekonomi dengan fungsi kegiatan yang dikembangkan adalah kegiatan perikanan [3]. Tujuan dari penetapan kawasan strategis pada wilayah pesisir utara Kota Pasuruan adalah untuk meningkatkan perekonomian kawasan dengan mengembangkan ekonomi lokal, sebagai upaya mendorong masuknya investasi, serta melindungi ekosistem pantai utara yang diwujudkan melalui pendekatan konsep pembangunan berkelanjutan pada kawasan pesisir.

Hal pokok yang menjadi pertimbangan pembangunan kawasan pesisir yang berkelanjutan adalah dengan mengembangkan kawasan pesisir secara mandiri berdasarkan potensi sosial ekonomi dengan tetap memperhatikan daya dukung serta kelestarian ekosistem pesisir dan laut, artinya pembangunan sumber daya pesisir dijalankan dengan mengintegrasikan setiap kepentingan dalam keseimbangan (proporsionality) antar dimensi ekologis, dimensi sosial, antar sektoral, disiplin ilmu dan segenap pelaku pembangunan (stakeholders) [4].

Akan tetapi, pada kawasan strategis ekonomi pesisir utara Kota Pasuruan ini kegiatan perikanannya belum menampakkan keseimbangan dari segi pengelolaan lingkungan, kondisi sosial masyarakat, pertumbuhan ekonomi, serta politik kelembagaannya. Hal ini dapat terlihat dari kondisi kawasan strategis pesisi utara Kota Pasuruan yang memiliki 
perkembangan jumlah produksi perikanan yang semakin menurun, serta diikuti dengan adanya kerusakan pada hutan mangrove yang merupakan tempat tinggal dan pemijahan ikan [5]. Penurunan jumlah produksi perikanan tangkap berpengaruh terhadap tingkat kesejahteraan nelayan yang mayoritas masih dalam kategori pra sejahtera. Permasalahan ini jika tidak segera ditangani secara komprehensif akan mengakibatkan terancamnya dan menurunnya keberlanjutan penghidupan masyarakat di wilayah pesisir utara Kota Pasuruan. Oleh karena itu, diperlukan suatu strategi pengembangan untuk meningkatkan keberlanjutan kawasan strategis ekonomi pesisir utara Kota Pasuruan khususnya melalui kegiatan perikanan.

Artikel ini merupakan salah satu tahapan dalam pengembangan kawasan strategis ekonomi wilayah pesisir utara Kota Pasuruan, dimana dalam artikel ini akan dibahas terkait variabel - variabel yang berpengaruh dalam pengembangan kawasan yang selanjutnya akan dijadikan input dalam penilaian tingkat keberlanjutan kawasan serta digunakan dalam perumusan strategi pengembangan kawasan tersebut.

\section{METODE PENELITIAN}

Penentuan variabel - variabel berpengaruh pada pengembangan kawasan strategis ekonomi pesisir utara di Kota Pasuruan ini dilakukan dengan menggunakan teknik analisis Delphi. Tahapan yang dilakukan untuk mendapatkan variabel - variabel berpengaruh tersebut dijelaskan melalui 4 tahap yang dapat dilihat pada uraian berikut.

\section{A. Kajian Pustaka}

Untuk mendapatkan variabel apa saja yang brepengaruh pada pengembangan kawasan strategis ekonomi pesisir utara Kota Pasuruan, maka terlebih dahulu dilakukan kajian pustaka. Kajian pustaka ang dilakukan adalah terkait komponen pengembangan pada kawasan strategis ekonomi, pengembangan wilayah pesisir, serta prinsip pembangunan berkelanjutan di wilayah pesisir yang dikembangkan oleh [4][6]-[7]. Variabel - variabel yang didapatkan dari hasil kajian pustaka ini dikategorikan ke dalam 4 dimensi yang menjadi pilar dalam pembangunan berkelanjutan, yaitu dimensi ekologi, sosial budaya, ekonomi, dan politik kelembagaan.

Berikut ini variabel - variabel hasil kajian pustaka yang merupakan variabel awal yang akan dianalisis dengan teknik Delphi untuk selanjutnya memperoleh variabel yang berpengaruh pada pengembangan kawasan strategis ekonomi pesisir utara pada bidang perikanan di Kota Pasuruan.

\section{B. Populasi dan Sampel}

Penentuan variabel berpengaruh memerlukan sampel yang benar - benar memahami wilayah dan objek penelitian, hal tersebut dilakukan dengan tujuan untuk memperoleh data dan informasi yang mendetail dan akurat, sehingga populasi yang digunakan dalam penelitian ini adalah narasumber yang memiliki pengaruh dan kepentingan dalam pengembangan
Tabel 1.

Variabel yang diteliti dalam penelitian

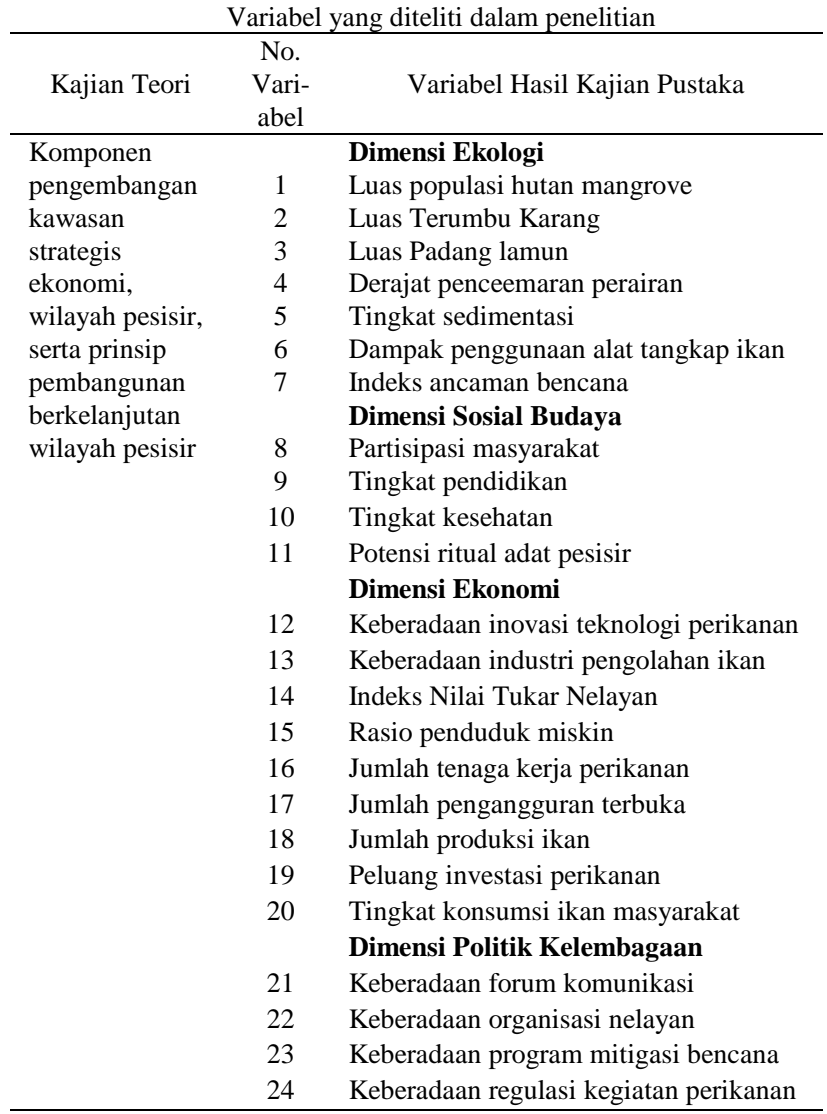

Sumber: Hasil Kaiian Pustaka. 2015

kawasan strategis ekonomi pesisir utara pada bidang perikanan di Kota Pasuruan. Berdasarkan populasi yang telah ditetapkan tersebut, maka pemilihan sampel dalam penelitian ini dilakukan dengan menggunakan teknik purposive sampling yakni pengambilan sampel orang-orang yang terpilih oleh peneliti menurut ciri-ciri spesifik dan karakteristik tertentu yang ditetapkan melalui Kriteria Responden.

\section{Metode Pengumpulan Data}

Teknik pengumpulan data adalah cara yang digunakan oleh peneliti untuk memperoleh data yang dibutuhkan [8]. Adapun cara untuk mendapatkan data untuk menjawab tujuan penelitian adalah melalui data primer dengan bantuan kuesioner dan wawancara. Kuesioner tersebut berisi daftar daftar pertanyaan yang telah disusun dan dibagikan kepada para responden, sekaligus merupakan panduan untuk melakukan wawancara yang bertujuan untuk menggali informasi mendalam terkait jawaban yang diberikan responden.

\section{Teknik Analisis Delphi}

Metode Delphi, merupakan teknik validasi variabel yang melibatkan pendapat pakar/stakeholders dan sejenisnya bagi isu pembangunan berkelanjutan pada kawasan strategis ekonomi di wilayah pesisir utara Kota Pasuruan. Metode Delphi akan mengumpulkan pemikiran para pakar/ahli dengan menggunakan kuesioner dan tambahan opini timbal balik. Prosedur metode Delphi yang dilakukan pada penelitian ini adalah sebagai berikut. 


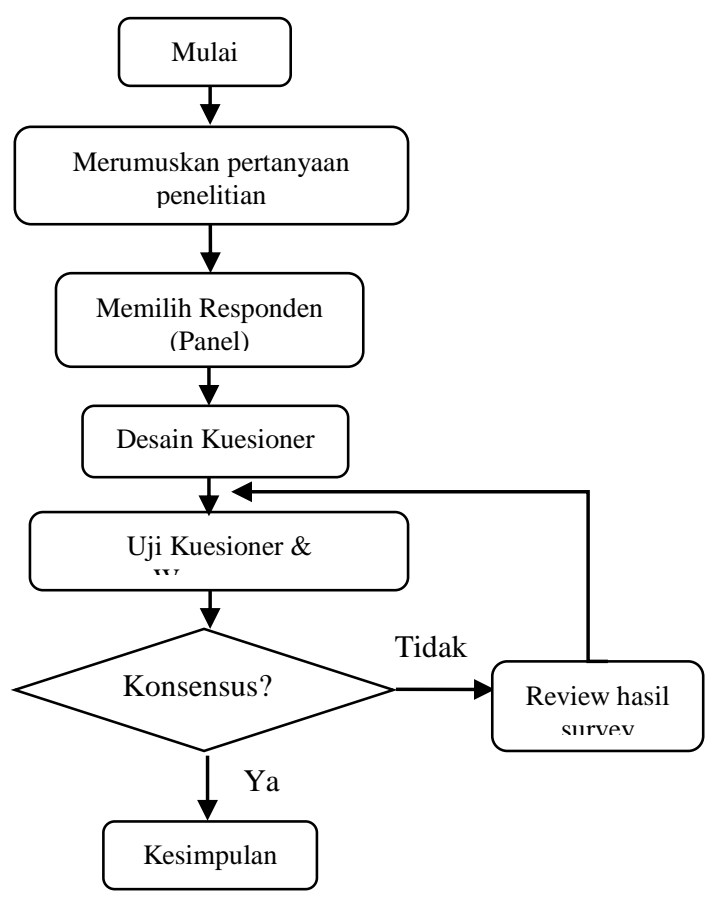

Gambar. 1. Langkah - langkah teknik Delphi

1) Identifikasi Masalah

Mengidentifikasi isu dan masalah yang berkembang atau permasalahan yang harus segera perlu diselesaikan.

2) Memilih dan Seleksi Responden

Pemilihan partisipan/responden harus diseleksi menggunakan dasar yang kuat, yakni berdasarkan bidang permasalahan dan isu yang telah teridentifikasi. Responden pada penelitian dipilih menggunakan pendekatan purposive sampling dan diseleksi menggunakan kriteria responden.

3) Merumuskan Kuesioner I

Menyusun butir - butir instrumen berdasarkan variabel yang diamati atau permasalahan yang akan diselesaikan berupa pertanyaan untuk digunakan pada putaran pertama dan selanjutnya.

4) Putaran Delphi I

Proses yang diterapkan pada putaran Delphi I ini adalah melalui wawancara berdasarkan variabel pada kuesioner kepada responden terpilih. Responden diminta untuk mengidentifikasi variabel mana yang berpengaruh (yang tertera pada kuesioner) terhadap pengembangan kawasan strategis ekonomi wilayah pesisir utara di Kota Pasuruan.

5) Analisis Hasil Putaran Delphi I

Tahap ini dilakukan setelah putaran Delphi I selesai. Adapun langkah dalam menganalisis hasil putaran Delphi I adalah sebagai berikut.

a. Menginterpretasikan pendapat responden berdasarkan hasil wawancara dan kuesioner.

b. Mengeliminasi butir instrumen / variabel pada kuesioner yang tidak sesuai.

c. Menyusun pertanyaan untuk kuesioner pada putaran Delphi II dan seterusnya serta mengkomunikasikan hasil analisis putaran I kepada responden.
6) Pengembangan Kuesioner Berikutnya

Kuesioner hasil review pada putaran Delphi I dikembangkan dan diperbaiki, kemudian dilanjutkan pada putaran Delphi kedua, dan ketiga (sesuai kebutuhan sampai tercapainya konsensus), dengan prinsip bahwa hasil analisis Delphi sebelumnya dijadikan input untuk analisis selanjutnya. Proses iterasi/putaran berhenti jika sudah terjadi konsensus.

\section{HASIL DAN DISKUSI}

\section{A. Responden Terpilih}

Penentuan pakar sebagai responden dalam penelitian ini menggunakan metode purposive sampling dengan pendekatan kriteria responden, yakni cara mendapatkan responden yang disesuaikan dengan tujuan penelitian. Dalam pelaksanaan pengembangan kawasan strategis ekonomi pesisir utara pada bidang perikanan di Kota Pasuruan ini, terdapat pihak - pihak (stakeholder) yang berwenang dan bertanggungjawab yakni pemerintah, masyarakat, serta swasta (badan usaha), sehingga responden yang terpilih merupakan representatif dari pihakpihak tersebut. Berikut ini para stakeholder yang telah memenuhi kriteria responden serta layak dijadikan sumber informasi bagi jalannya penelitian ini.

Tabel 2.

\begin{tabular}{lc}
\multicolumn{2}{c}{ Responden dalam penelitian } \\
\hline Bidang Ahli & $\begin{array}{c}\text { Kode } \\
\text { Responden }\end{array}$ \\
\hline $\begin{array}{l}\text { BAPPEDA bidang fisik prasarana } \\
\text { dan bidang ekonomi sosial budaya }\end{array}$ & $\mathrm{R} 1$ \\
& $\mathrm{R} 2$ \\
Dinas Pertanian, Kehutanan, & $\mathrm{R} 3$ \\
Kelautan, dan Perikanan (DPKKP) & \\
$\begin{array}{l}\text { Kelurahan Tambaan } \\
\text { Kelurahan Ngemplakrejo }\end{array}$ & $\mathrm{R} 4$ \\
Kelurahan Panggungrejo & $\mathrm{R} 5$ \\
\hline $\begin{array}{l}\text { Ketua Kelompok nelayan } \\
\text { Pelaku Pengolahan Hasil Produksi }\end{array}$ & $\mathrm{R} 7$ \\
Ikan & $\mathrm{R} 8$ \\
Sumber: Hasil Analisis, 2015 &
\end{tabular}

\section{B. Hasil Delphi Putaran I}

Pada tahap ini, peneliti menggunakan kuesioner yang berisi variabel - variabel penelitian (Tabel 1) sebagai panduan diskusi dan wawancara. Kuesioner yang telah disusun digunakan untuk mengeksplor pendapat responden sekaligus memudahkan peneliti untuk melihat kecenderungan responden dalam menanggapi variabel - variabel pada kuesioner sehingga dapat diketahui variabel mana saja yang berpengaruh terhadap pengembangan kawasan strategis ekonomi wilayah pesisir utara di Kota Pasuruan.

Bentuk eksplorasi jawaban dari responden pada tiap tiap variabel adalah "setuju" (dengan representatif angka ' 1 ') atau "tidak setuju" (dengan representatif angka ' 0 ') variabel tersebut mempunyai pengaruh terhadap pengembangan kawasan strategis ekonomi wilayah pesisir utara pada Bidang perikanan di Kota Pasuruan. Adapun rekapitulasi dari jawaban responden dapat dilihat pada Tabel 3 berikut.

Tabel 3.

Hasil Eksplorasi Delphi Putaran I 


\begin{tabular}{|c|c|c|c|c|c|c|c|c|c|}
\hline \multirow{2}{*}{ Variabel } & \multicolumn{8}{|c|}{ Responden } & \multirow[t]{2}{*}{ Ket } \\
\hline & R1 & $\mathrm{R} 2$ & R3 & $\mathrm{R} 4$ & $\mathrm{R} 5$ & R6 & R7 & R8 & \\
\hline Variabel 1 & 1 & 1 & 1 & 1 & 1 & 1 & 1 & 1 & $\mathrm{~K}$ \\
\hline Variabel 2 & 0 & 0 & 0 & 0 & 1 & 0 & 1 & 0 & TK \\
\hline Variabel 3 & 0 & 0 & 0 & 0 & 0 & 0 & 0 & 0 & TK \\
\hline Variabel 4 & 1 & 1 & 1 & 1 & 1 & 1 & 1 & 1 & $\mathrm{~K}$ \\
\hline Variabel 5 & 1 & 1 & 1 & 1 & 1 & 1 & 1 & 1 & K \\
\hline Variabel 6 & 1 & 1 & 1 & 1 & 1 & 1 & 1 & 1 & $\mathrm{~K}$ \\
\hline Variabel 7 & 1 & 1 & 0 & 0 & 1 & 0 & 1 & 1 & TK \\
\hline Variabel 8 & 1 & 1 & 1 & 1 & 1 & 1 & 1 & 1 & $\mathrm{~K}$ \\
\hline Variabel 9 & 1 & 1 & 1 & 1 & 1 & 1 & 1 & 1 & K \\
\hline Variabel 10 & 1 & 1 & 1 & 1 & 1 & 1 & 1 & 1 & $\mathrm{~K}$ \\
\hline Variabel 11 & 1 & 0 & 1 & 1 & 1 & 1 & 1 & 1 & TK \\
\hline Variabel 12 & 1 & 1 & 1 & 1 & 1 & 1 & 1 & 1 & K \\
\hline Variabel 13 & 1 & 1 & 1 & 1 & 1 & 1 & 1 & 1 & $\mathrm{~K}$ \\
\hline Variabel 14 & 1 & 1 & 1 & 0 & 1 & 1 & 1 & 1 & TK \\
\hline Variabel 15 & 1 & 1 & 1 & 1 & 1 & 1 & 1 & 1 & K \\
\hline Variabel 16 & 1 & 1 & 0 & 1 & 1 & 1 & 1 & 1 & TK \\
\hline Variabel 17 & 1 & 1 & 1 & 1 & 1 & 1 & 1 & 1 & $\mathrm{~K}$ \\
\hline Variabel 18 & 1 & 1 & 0 & 0 & 1 & 1 & 1 & 1 & TK \\
\hline Variabel 19 & 1 & 1 & 1 & 1 & 1 & 1 & 1 & 1 & $\mathrm{~K}$ \\
\hline Variabel 20 & 1 & 1 & 0 & 0 & 1 & 1 & 1 & 1 & TK \\
\hline Variabel 21 & 1 & 1 & 1 & 1 & 1 & 1 & 1 & 1 & K \\
\hline Variabel 22 & 1 & 1 & 1 & 1 & 1 & 1 & 1 & 1 & $\mathrm{~K}$ \\
\hline Variabel 23 & 1 & 1 & 0 & 0 & 1 & 0 & 1 & 1 & TK \\
\hline Variabel 24 & 1 & 1 & 1 & 1 & 1 & 1 & 1 & 1 & $\mathrm{~K}$ \\
\hline $\begin{array}{r}0-\text { Resp } \\
\text { variabel yan } \\
1-\text { Respo } \\
\text { yang berpeng } \\
\text { K-Konse } \\
\text { variabel yan } \\
\text { TK - Tid } \\
\text { sama bahw } \\
\text { berpengaruh }\end{array}$ & $\begin{array}{l}\text { uhd } \\
\text { is, ya } \\
\text { ersan } \\
\text { Kon }\end{array}$ & $\begin{array}{l}\text { aruh } \\
\text { ju bo } \\
\text { am } p \\
\text { ii ser } \\
\text { kutar }\end{array}$ & $\begin{array}{l}\text { iwa } \\
\text { lgem } \\
\text { ua re } \\
\text { meru } \\
\text { yakn }\end{array}$ & $\begin{array}{l}\text { riabe } \\
\text { ingan } \\
\text { onde } \\
\text { akan } \\
\text { semu }\end{array}$ & $\begin{array}{l}\text { yang } \\
\text { kawe } \\
\text { men } \\
\text { arial } \\
\text { res }\end{array}$ & $\begin{array}{l}\text { iajuk } \\
\text { in per } \\
\text { iki re } \\
\text { berp } \\
\text { inden }\end{array}$ & $\begin{array}{l}\text { asan } \\
\text { n me } \\
\text { elitia } \\
\text { pon } \\
\text { ngar } \\
\text { mem }\end{array}$ & $\begin{array}{l}\text { kan } \\
\text { enelit } \\
\text { upaka }\end{array}$ & $\begin{array}{l}\text { variabel } \\
\text { a bahwa } \\
\text { on yang } \\
\text { l tidak }\end{array}$ \\
\hline
\end{tabular}

Berdasarkan hasil Delphi Putaran I diatas, terdapat 15 variabel yang sudah konsensus dan 9 variabel yang tidak konsensus, sehingga diperlukan putaran Delphi kembali sampai mencapai hasil konsensus pada seluruh variablel. Hasil Delphi Putaran I selain bertujuan untuk mengeksplor pendapat responden terhadap variabel penelitian, didapatkan pula variabel lain yang menurut responden memiliki pengaruh namun belum tercantum pada variabel - variabel penelitian yang telah dibentuk oleh peneliti. Cara untuk mendapatkan variabel baru, peneliti menanyakan langsung kepada responden yang bersangkutan, sehingga secara implisit responden mengungkapkan variabel lain yang memiliki pengaruh terhadap pengembangan kawasan strategis ekonomi wilayah pesisir utara pada bidang perikanan di Kota Pasuruan

Berdasarkan hasil eksplorasi wawancara Delphi Putaran I, peneliti merumuskan kembali variabel yang berpengaruh untuk kemudian diolah kembali pada Delphi Putaran II. Responden yang digunakan untuk iterasi Delphi II adalah sama dengan responden pada Delphi Putaran I. Berikut ini variabel variabel yang ditanyakan kembali kepada responden untuk mendapatkan variabel - variabel yang berpengaruh terhadap pengembangan kawasan strategis ekonomi wilayah pesisir utara pada bidang perikanan di Kota Pasuruan.

$$
\text { Tabel } 4 .
$$

Variabel untuk Delphi Putaran II

\begin{tabular}{|c|c|}
\hline Variabel & Keterangan \\
\hline Variabel 2 & \\
\hline Variabel 3 & \\
\hline Variabel 7 & Variabel \\
\hline
\end{tabular}

\begin{tabular}{lc}
\hline \multicolumn{1}{c}{ Variabel } & Keterangan \\
\hline Variabel 11 & Tidak \\
Variabel 14 & Konsensus \\
Variabel 16 & \\
Variabel 18 & \\
Variabel 20 & \\
Variabel 23 & \\
\hline Keberadaan Tempat Pelelangan & Variabel \\
Ikan & Baru \\
\hline Sumber: Hasil Analisis, 2015 &
\end{tabular}

\section{Hasil Delphi Putaran II}

Pada tahapan Delphi Putaran II, peneliti kembali mengeksplor pernyataan dari responden dengan melakukan penjelasan lebih dalam berdasarkan masing - masing variabel kepada responden. Peneliti juga mendiskusikan hasil pernyatan - pernyataan dari responden lain berkaitan dengan variabel penelitian berdasarkan hasil Delphi Putaran I.

Variabel baru 'Keberadaan Tempat Pelelangan Ikan' menjadi faktor pengembangan ekonomi, sehingga variabel Keberadaan TPI tergolong pada dimensi keberlanjutan ekonomi pada faktor infrastruktur yang pendukung kegiatan perikanan.

Tabel 5. Hasil Delphi Putaran II

\begin{tabular}{lccccccccc}
\hline \multicolumn{1}{c}{ Variabel } & \multicolumn{1}{c}{ Responden } & Ket \\
& R1 & R2 & R3 & R4 & R5 & R6 & R7 & R8 & \\
\hline Variabel 2 & 0 & 0 & 0 & 0 & 0 & 0 & 0 & 0 & $\mathrm{~K}$ \\
Variabel 3 & 0 & 0 & 0 & 0 & 0 & 0 & 0 & 0 & $\mathrm{~K}$ \\
Variabel 7 & 0 & 0 & 0 & 0 & 0 & 0 & 0 & 0 & $\mathrm{~K}$ \\
Variabel 11 & 1 & 1 & 1 & 1 & 1 & 1 & 1 & 1 & $\mathrm{~K}$ \\
Variabel14 & 1 & 1 & 1 & 1 & 1 & 1 & 1 & 1 & $\mathrm{~K}$ \\
Variabel 16 & 1 & 1 & 1 & 1 & 1 & 1 & 1 & 1 & $\mathrm{~K}$ \\
Variabel 18 & 1 & 1 & 1 & 1 & 1 & 1 & 1 & 1 & $\mathrm{~K}$ \\
Variabel 20 & 1 & 1 & 1 & 1 & 1 & 1 & 1 & 1 & $\mathrm{~K}$ \\
Variabel 23 & 0 & 0 & 0 & 0 & 0 & 0 & 0 & 0 & $\mathrm{~K}$ \\
\hline Keberadaan & 1 & 1 & 1 & 1 & 1 & 1 & 1 & 1 & $\mathrm{~K}$ \\
Tempat & & & & & & & & & \\
Pelelangan Ikan & & & & & & & & & \\
\hline
\end{tabular}

Sumber: Hasil Analisis, 2015

\section{Kesimpulan Hasil Analisis Delphi}

Metode Delphi yang digunakan untuk menganalisis variabel berpengaruh pada pengembangan kawasan strategis ekonomi wilayah pesisir utara pada bidang perikanan di Kota Pasuruan berjalan sebanyak 2 (dua) kali iterasi/putaran, artinya konsensus dari para responden dicapai pada Delphi Putaran II.

Berdasarkan hasil Analisis Delphi dalam menentukan variabel yang berpengaruh, dari 24 variabel yang dianalisis terdapat 4 (empat) variabel yang dieliminasi atau dihilangkan karena tidak berpengaruh. Variabel yang tidak berpengaruh antara lain: variabel luas terumbu karang, luas padang lamun, indeks ancaman bencana, dan keberadaan program mitigasi bencana. Selain itu, terdapat pula 1 variabel baru yakni variabel keberadaan tempat pelelangan ikan yang merupakan salah satu variabel penentu keberlanjutan ekonomi.

$$
\text { Tabel } 6 .
$$

\begin{tabular}{cc}
\multicolumn{2}{l}{ Variabel yang Berpengaruh pada Pengembangan Kawasan Penelitian } \\
\hline No & \multicolumn{1}{c}{ Variabel Berpengaruh } \\
\hline Keberlanjutan Lingkungan \\
1 & Luas populasi hutan mangrove \\
2 & Derajat pencemaran perairan \\
3 & Tingkat sedimentasi
\end{tabular}




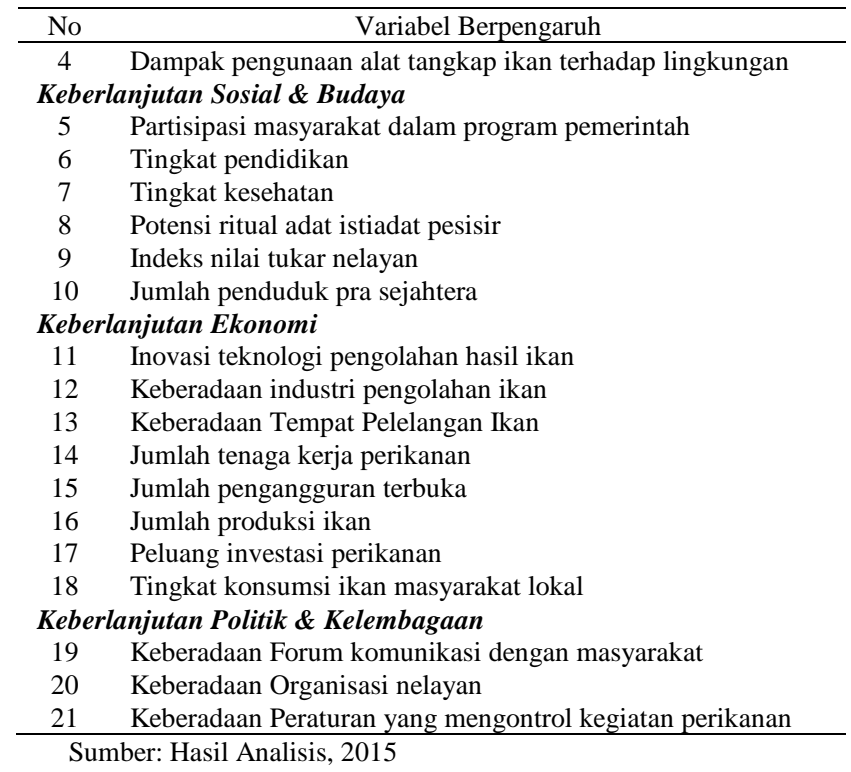

\section{KESIMPULAN}

Penentuan variabel yang berpengaruh dalam pengembangan kawasan strategis ekonomi wilayah pesisir utara pada bidang perikanan di Kota Pasuruan ini diperlukan untuk dapat merumuskan strategi pengembangan dengan menggunakan pendekatan konsep pembangunan berkelanjutan, agar tujuan penetapan kawasan strategis yakni untuk meningkatkan kesejahteraan masyarakat pesisir melalui pengembangan kegiatan ekonomi lokal, mendorong masuknya investasi, serta sebagai perlindungan terhadap ekosistem pantai utara dapat terealisasikan.

Terdapat 21 variabel yang berpengaruh dalam pengembangan kawasan strategis ekonomi pesisir utara pada bidang perikanan di Kota Pasuruan yang diperoleh dengan menggunakan teknik analisis Delphi sebanyak II Putaran.

Variabel - variabel berpengaruh ini nantinya akan menjadi input untuk merumuskan strategi pengembangan kawasan yang dikategorikan berdasarkan 4 pilar pembangunan berkelanjutan, yakni dimensi ekologi, sosial budaya, ekonomi, serta politik kelembagaan.

\section{DAFTAR PUSTAKA}

[1] Data Badan Pusat Statistik Kota Pasuruan tahun 2009-2013,

[2] Buku Putih Percepatan Pembangunan Sanitasi Permukiman Kota Pasuruan Tahun 2009

[3] Peraturan Daerah Kota Pasuruan No 1 Tahun 2012 tentang RTRW Kota Pasuruan tahun 2011-2031

[4] Dahuri, Rokhmin, dkk. 2001.Pengelolaan Sumber Daya Wilayah Pesisir dan Lautan Secara Terpadu. Jakarta: Penerbit Pradnya Paramita

[5] Data Dinas Pertanian, Kehutanan, Kelautan dan Perikanan Kota Pasuruan

[6] Wiyana, Adi. 2004. Faktor Berpengaruh Terhadap Keberlanjutan Pengelolaan Pesisir Terpadu (P2T). Makalah Pengantar Falsafah Sains (PPs 702). Program Pasca Sarjana Institut Pertanian Bogor.

[7] Zulkifli, Arif . 2014. Dasar - Dasar Ilmu Lingkungan. Jakarta: Penerbit Salemba Teknika

[8] Arikunto S, 2006. Prosedur Penelitian Suatu Pendekatan Praktik, Ed Revisi VI, Penerbit PT Rineka Cipta; Jakarta 